\title{
Pengaruh Pembiayaan Mudharabah dan Musyarakah Terhadap Profitabilitas (ROA) Pada BPRS HIK Bekasi Kantor Cabang Karawang
}

\author{
Ahmad Nawawi, Dian Hakip Nurdiansyah, \\ Diffah Sri Addafi Al Qodliyah \\ Fakultas Ekonomi dan Bisnis, \\ Universitas Singaperbangsa Karawang, Indonesia \\ E-mail: Dian.hakipnurdiansyah@staff.unsika.ac.id
}

\begin{abstract}
The purpose of this study was to analyze the effect of mudharabah and musyarakah financing on profitability (ROA) at BPRS HIK Bekasi Karawang Branch Office. The research method using descriptive quantitative method with population is all quarterly financial statements of BPRS HIK Bekasi Karawang Branch Office. The results of the research conducted show that: (1) mudharabah financing has a positive and not significant effect on profitability BPRS HIK Bekasi Return on Assets (ROA) Karawang Branch Office 2009-2016 partially. This is evidenced by the sig value. $0.187>0.05$ and the value of $t$ count is $1.351<\mathrm{t}$ table 2.042. (2) Musyarakah financing has significant negative effect on profitability BPRS HIK Bekasi Return on Assets (ROA) Branch Office Karawang 2009-2016 period partially. This is evidenced by sig. $0,000<0,05$ and the value of $t$ count is $-7,560>t$ table 2,042. (3) Mudharabah financing and musyarakah financing have a significant effect on profitability BPRS HIK Bekasi Return on Assets (ROA) Karawang Branch Office 2009-2016 period simultaneously. This is evidenced by the sig value. $0.000<0.05$ and the calculated $f$ value is 31.022> f table 3.32.
\end{abstract}

Keywords: Mudharabah financing, Musharaka financing and profitability Return on Assets (ROA) 


\begin{abstract}
ABSTRAK
Tujuan penelitian ini untuk menganalisis pengaruh pembiayaan mudharabah dan musyarakah terhadap profitabilitas (ROA) pada BPRS HIK Bekasi Kantor Cabang Karawang. Metode penelitian menggunakan metode deskriptif kuantitatif dengan populasi adalah semua laporan keuangan Triwulan BPRS HIK Bekasi Kantor Cabang Karawang. Hasil penelitian yang dilakukan menunjukkan bahwa : (1) pembiayaan mudharabah berpengaruh positif dan tidak signifikan terhadap profitabilitas Return on Assets (ROA) BPRS HIK Bekasi Kantor Cabang Karawang periode 2009-2016 secara parsial. Hal tersebut dibuktikan dengan nilai sig. $0.187>0,05$ dan nilai t hitung yakni $1,351<\mathrm{t}$ tabel 2,042. (2) Pembiayaan musyarakah berpengaruh negatif signifikan terhadap profitabilitas Return on Assets (ROA) BPRS HIK Bekasi Kantor Cabang Karawang periode 2009-2016 secara parsial. Hal tersebut dibuktikan dengan sig. $0.000<0,05$ dan nilai $\mathrm{t}$ hitung yakni $-7,560>\mathrm{t}$ tabel 2,042. (3) Pembiayaan mudharabah dan pembiayaan musyarakah berpengaruh signifikan terhadap profitabilitas Return on Assets (ROA) BPRS HIK Bekasi Kantor Cabang Karawang periode 2009-2016 secara simultan. Hal tersebut dibuktikan dengan nilai sig. $0.000<0,05$ dan nilai f hitung yakni 31,022 > f tabel 3,32.
\end{abstract}

Kata Kunci: Pembiayaan mudharabah, Pembiayaan musyarakah dan profitabilitas Return On Asset (ROA).

\title{
1. Pendahuluan
}

Perbankan di Indonesia mengalami perkembangan dengan seiring berkembangnya pemikiran masyarakat tentang sistem syariah yang tanpa menggunakan bunga (riba). Bank terbagi menjadi dua, yaitu bank syariah dan bank konvensional. Kedua jenis bank ini memiliki produk bank yang hampir sama, hanya berbeda pada sistem operasinya. Bank konvensional menggunakan sistem bunga, sedangkan bank syariah menerapkan sistem bagi hasil. Produk bank yang menerapkan sistem bagi hasil adalah mudharabah dan musyarakah. Suatu bank akan dinilai baik kinerja usahanya apabila dinilai dari rasio keuangannya. Rasio merupakan alat yang dinyatakan dalam artian relatif maupun absolut untuk menjelaskan hubungan tertentu antara faktor satu dengan yang lainnya dari suatu laporan keuangan, salah satu rasio yang terpenting adalah rasio profitabilitas. Profitabilitas mempunyai arti penting dalam usaha mempertahankan kelangsungan hidup perusahaan dalam jangka panjang, karena profitabilitas menunjukkan apakah perusahaan tersebut mempunyai prospek yang baik di masa yang akan datang (Harahap, 2008: 305).

Pembiayaan mudharabah dan musyarakah merupakan salah satu faktor yang mempengaruhi tingkat keuntungan di BPRS HIK Bekasi Kantor Cabang Karawang. Keuntungan itu dapat dilihat dari tingkat profitabilitas yang diukur menggunakan rasio keuangan. Rasio keuangan yang digunakan adalah rasio Return On Asset (ROA) yaitu adalah rasio untuk mengukur tingkat laba terhadap 
aktiva yang dimiliki oleh perusahaan tersebut. Ada beberapa penelitian yang mengemukakan pembiayaan Murabahah, Musyarakah, dan biaya transaksi memiliki pengaruh signifikan terhadap profitabiltas (ROA) Bank Pembiayaan Bank Rakyat Syariah (Agza \& Darwanto, 2016). Fenomena yang terjadi yaitu terjadi penurunan dan kenaikan antara pembiayaan mudharabah, musyarakah dan Return On Asset pada setiap tahunnya. Berdasarkan hal di atas, maka tulisan ini membahas tentang pembiayaan mudharabah dan musyarakah terhadap profitabilitas melalui pendekatan Return On Asset (ROA).

\section{Kajian Pustaka}

Menurut Muhammad (2012: 11) akuntansi syariah adalah akuntansi yang mempunyai tiga komponen prinsip yaitu prinsip pertanggungjawaban (Accountability), prinsip keadilan dan prinsip kebenaran yang berdasarkan pada hukum syariah dan bersifat universal. Menurut Nurhayati dan Wasilah (2013:2) secara sederhana pengertian akuntansi syariah dapat dijelaskan melalui akar kata yang dimilikinya yaitu akuntansi dan syariah, definisi bebas dari akuntansi adalah identifikasi transaksi yang kemudian diikuti dengan kegiatan pencatatan, penggolongan, serta pengikhtisaran transaksi tersebut sehingga menghasilkan laporan keuangan yang dapat digunakan untuk pengambilan keputusan. Definisi bebas dari syariah adalah aturan yang telah ditetapkan Allah SWT untuk dipatuhi oleh manusia dalam menjalani segala aktivitas hidupnya di dunia, jadi akuntansi syariah dapat diartikan sebagai proses akuntansi atas transaksi-transaksi yang sesuai dengan aturan yang diterapkan Allah SWT. Sedangkan Bank syariah adalah lembaga keuangan negara yang memberikan kredit dan jasa-jasa lainnya di dalam lalu lintas pembayaran dan juga peredaran uang yang beroperasi dengan menggunakan prinsip-prinsip syariah atau islam (Sudarsono, 2012: 29).

Pembiayaan mudharabah adalah kerjasama antara seorang partner yang memberikan uang kepada partner lain untuk diinvestasikan ke perusahaan komersial. Pihak bank (mudharib) berkewajiban memberikan dana 100\% kepada nasabah (shahibul maal) dan mudharib hanya mengelola usaha yang sudah ditentukan oleh pihak shahibul maal. Pembagian keuntungan akan dibagi berdasarkan kesepakatan pada awal kontrak, sedangkan jika terjadi kerugian akan ditanggung oleh pemilik modal. Pengelola juga bertanggungjawab apabila kerugian itu disebabkan oleh pihak pengelola (Rivai \& Arifin, 2012: 299). Menurut Ismail (2011: 60) dalam Wibowo dan Sunarto (2014), Mudharabah merupakan akad bagi hasil ketika pemilik dana, bisa disebut shahibul mal/rabbul mal, menyediakan modal 100 persen kepada pengusaha sebagai pengelola, biasa disebut mudharib. Untuk melakukan aktivitas produktif dengan syarat bahwa keuntungan yang dihasilkan akan dibagi di antara mereka menurut kesepakatan yang ditentukan sebelumnya dalam akad (yang besarnya juga dipengaruhi oleh kekuatan pasar).

Pembiayaan musyarakah adalah kerjasama dimana dua atau lebih pengusaha bekerjasama sebagai mitra usaha dalam bisnis. Masing-masing pihak 
menyertakan modalnya dan ikut mengelola usaha tersebut. Keuntungan dan kerugian akan dibagi berdasarkan persentase penyertaan modalnya (Ascarya, 2011: 51) Menurut Harahap, Wiroso dan Yusuf (2010: 475) dalam Muslim dan Julimursyida (2014), musyarakah adalah akad kerja sama diantara para pemilik modal yang mencampurkan modal mereka untuk tujuan mencari keuntungan. Rukun syirkah menurut Hanafiayah, syirkah ada dua, yaitu ijab dan kabul, sebab ijab kabul (akad) yang menentukan syirkah. Adapun yang lain seperti dua orang atau pihak yang berakad dan harta berada di luar pembahasan akad, seperti terdahulu dalam akad jual beli (Suhendi, 2007: 127). Menurut Kasmir (2012: 196) rasio profitabilitas adalah rasio untuk menilai kemampuan perusahaan dalam mencari keuntungan. Menurut Mamduh (2008: 42) rasio profitabilitas adalah rasio untuk mengukur kemampuan perusahaan menghasilkan keuntungan (profitabilitas) pada tingkat penjualan, aset, modal saham tertentu.

Menurut Prastowo (2008: 95) Return On Asset mengukur kemampuan perusahaan dalam memanfaatkan aktivanya untuk memperoleh laba yang telah dilakukan oleh perusahaan dengan menggunakan seluruh aktiva yang dimilikinya. Menurut Prihadi (2010: 196) Return On Asset (ROA) merupakan rasio yang mengukur tingkat laba terhadap aset yang digunakan dalam menghasilkan laba perbankan tersebut.

\section{Metode Penelitian}

Tujuan penelitian ini adalah untuk mengetahui pengaruh pembiayaan mudharabah dan musyarakah terhadap profitabilitas (ROA) pada BPRS HIK Bekasi Kantor Cabang Karawang. Dengan memperhatikan tujuan tersebut, maka metode penelitian yang digunakan adalah metode analisis deskriptif dengan pendekatan yang digunakan adalah kuantitatif. Menurut Arikunto \& Suharsimi (2010: 3) deskriptif adalah penelitian yang dimaksudkan untuk menyelidiki keadaan, kondisi atau hal lain-lain yang sudah disebutkan, yang hasilnya dipaparkan dalam bentuk laporan penelitian.

4. Hasil dan Pembahasan

4.1. Pengaruh Pembiayaan Mudharabah dan Musyarakah terhadap profitabilitas (ROA)

Tabel 1.1: Uji Normalitas

\begin{tabular}{|l|l|l|}
\hline \multicolumn{2}{|c|}{} & $\begin{array}{l}\text { Unstandardized } \\
\text { Residual }\end{array}$ \\
\hline $\mathbf{N}$ & $\mathbf{3 2}$ \\
\hline Normal Parameters & Mean &, 0000000 \\
\cline { 2 - 3 } & Std. & 1,16476215 \\
& Deviation & \\
\hline Most Extreme Differences & Absolute &, 124 \\
\hline
\end{tabular}




\begin{tabular}{|l|l|l|}
\hline & Positive &, 124 \\
\cline { 2 - 3 } & Negative &,- 066 \\
\hline Test Statistic &, 124 \\
\hline Asymp. Sig. (2-tailed) &, $200^{c, d}$ \\
\hline
\end{tabular}

Sumber : Data diola, 2018

Berdasarkan tabel 1 diperoleh nilai Asymp. Sig. (2-tailed) dari hasil uji Kolmogorov-Smirnov sebesar 0,200 dengan tingkat kekeliruan 0,05 maka dapat disimpulkan bahwa model regresi berdistribusi normal.

Tabel 1.2: Uji Multikolonieritas

Coefficients $^{\mathbf{a}}$

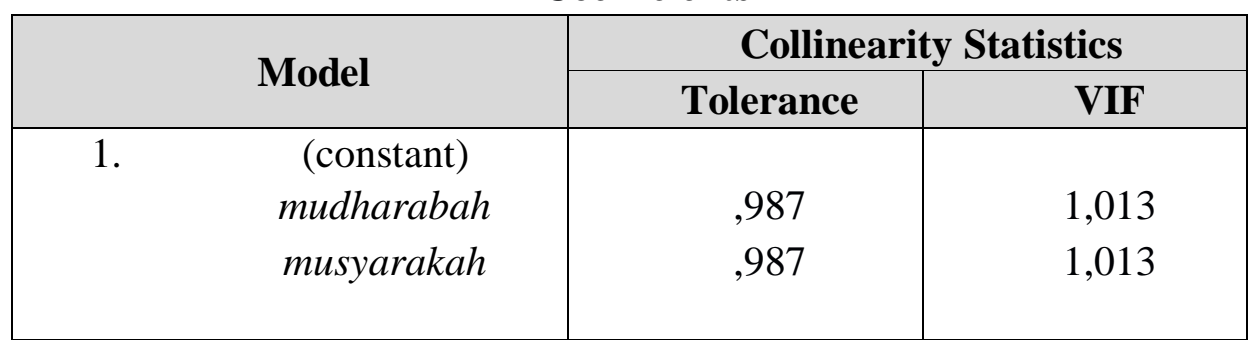

Sumber : Data diolah SPSS 24.

Berdasarkan tabel diatas dapat diketahui nilai tolerance dan VIF untuk masingmasing variabel sebagai berikut: pertama, nilai tolerance untuk variabel pembiayaan mudharabah sebesar 0, $987>0.10$ dan nilai VIF sebersar 1,013<10, sehingga variabel pembiayaan mudharabah dinyatakan tidak terjadi multikolinieritas. kedua, nilai tolerance untuk variabel pembiayaan musyarakah sebesar $0,987>0.10$ dan nilai VIF sebersar $1,013<10$, sehingga variabel pembiayaan musyarakah dinyatakan tidak terjadi multikolinieritas.

Tabel 1.3: Statistik Deskriptif

Descriptive Statistics

\begin{tabular}{|l|r|c|c|c|c|}
\hline & $\mathrm{N}$ & Minimum & Maximum & Mean & Std. Deviation \\
\hline Mudharabah & 32 & 11,74 & 14,18 & 12,8999 &, 66950 \\
\hline Musyarakah & 32 & 14,55 & 15,98 & 15,4945 &, 35413 \\
\hline ROA & 32 & 2,85 & 11,48 & 6,3275 & 2,06377 \\
\hline $\begin{array}{l}\text { Valid N } \\
\text { (listwise) }\end{array}$ & 32 & & & & \\
\hline
\end{tabular}

Berdasarkan tabel diatas, diketahui bahwa terdapat tiga variabel penelitian (pembiayaan mudharabah, musyarakah dan ROA). Dengan jumlah sampel secara 
keseluruhan sebanyak 32 sampel. Beberapa penjelasan mengenai hasil perhitungan statistik diuraikan sebagai berikut:

1) Pembiayaan Mudharabah

Dari hasil pengujian statistik deskriptif, pembiayaan mudharabah BPRS HIK Bekasi kantor cabang Karawang memiliki nilai terendah (minimun) sebesar 11,74, nilai tertinggi (maximum) 14,48, nilai rata-rata (mean) 12,8999 dan standar deviasi sebesar 2,06377.

2) Pembiayaan Musyarakah

Dari hasil pengujian statistik deskriptif, pembiayaan musyarakah BPRS HIK Bekasi kantor cabang Karawang memiliki nilai terendah (minimun) sebesar 14,55, nilai tertinggi (maximum) 15,98, nilai rata-rata (mean) 6,3275 dan standar deviasi sebesar 0,35413. Sebagaimana menurut Menurut Sumiyato (2008:165), Pembiayaan adalah aktivitas menyalurkan dana yang terkumpul kepada anggota pengguna dana, memilih jenis usaha yang akan dibiayai agar diperoleh jenis usaha yang produktif, menguntungkan dan dikelola oleh anggota yang jujur dan bertanggung jawab.

3) Profitabilitas (ROA)

Dari hasil pengujian statistik deskriptif, pembiayaan musyarakah BPRS HIK Bekasi kantor cabang Karawang memiliki nilai terendah (minimun) sebesar 2,85, nilai tertinggi (maximum) 11,48, nilai rata-rata (mean) 15,4945 dan standar deviasi sebesar 0,35413.

Tabel 1.4: Persamaan Regresi

Coefficients $^{\mathrm{a}}$

\begin{tabular}{|c|c|c|c|c|c|}
\hline \multirow{2}{*}{ Model } & \multicolumn{2}{|c|}{$\begin{array}{l}\text { Unstandardized } \\
\text { Coefficients }\end{array}$} & \multirow{2}{*}{$\begin{array}{c}\begin{array}{c}\text { Standardized } \\
\text { Coefficients }\end{array} \\
\text { Beta }\end{array}$} & \multirow{2}{*}{$\mathbf{t}$} & \multirow{2}{*}{ Sig. } \\
\hline & B & Std. Error & & & \\
\hline (Constant) & 72,659 & 10,829 & & 6,710 & 000 \\
\hline Mudharabah & ,439 & ,325 &, 142 & 1,351 & , 187 \\
\hline Musyarakah & $-4,647$ & ,615 &,- 797 & $-7,560$ & ,000 \\
\hline
\end{tabular}

Berdasarkan persamaan regresi di atas maka dapat dilakukan interprestasikan sebagai berikut: pertama, nilai konstanta persamaan diatas adalah 72,659. Angka tersebut menunjukkan ROA bank apabila variabel pembiayaan mudharabah (X1) dan pembiayaan musyarakah (X2) bernilai 0 (nol), maka profitabilitas (ROA) nilainya sebesar 72,659. Kedua, variabel pembiayaan mudharabah memiliki nilai koefisien regresi yang positif yaitu sebesar 0,439. 
Nilai koefisien yang positif ini menunjukkan bahwa pembiayaan mudharabah berpengaruh positif terhadap ROA. Hal ini menggambarkan setiap kenaikan tingkat pembiayaan mudharabah sebesar 1 satuan maka ROA akan mengalami peningkatan sebesar 0,439. Ketiga, variabel pembiayaan musyarakah memiliki nilai koefisien regresi yang negatif yaitu sebesar -4,647. Nilai koefisien yang negatif ini menunjukkan bahwa pembiayaan musyarakah berpengaruh negatif terhadap ROA. Hal ini berarti setiap kenaikan tingkat pembiayaan musyarakah sebesar 1 satuan maka ROA akan mengalami penurunan sebesar -4,647.

Tabel 1.5: Uji Signifikan Parsial (Uji-T)

Coefficients $^{\mathrm{a}}$

\begin{tabular}{|c|c|c|c|c|c|}
\hline \multirow{2}{*}{ Model } & \multicolumn{2}{|c|}{$\begin{array}{c}\text { Unstandardized } \\
\text { Coefficients }\end{array}$} & \multicolumn{2}{c|}{$\begin{array}{c}\text { Standardized } \\
\text { Coefficients }\end{array}$} & Sig. \\
\cline { 2 - 5 } & B & $\begin{array}{c}\text { Std. } \\
\text { Error }\end{array}$ & Beta & & t \\
\hline (Constant) & 72,659 & 10,829 & & 6,710 &, 000 \\
Mudharabah &, 439 &, 325 &, 142 & 1,351 &, 187 \\
Musyarakah & $-4,647$ &, 615 &,- 797 & $-7,560$ &, 000 \\
\hline
\end{tabular}

Berdasarkan tabel di atas, hipotesis pengaruh pembiayaan mudharabah terhadap profitabilitas (ROA) menunjukkan bahwa nilai sig. $0.187>0,05$ dan nilai t hitung 1,351 < t tabel 2,042. Dengan demikian dapat disimpulkan bahwa pembiayaan mudharabah secara parsial tidak berpengaruh signifikan terhadap profitabilitas (ROA) dan bernilai positif. hal ini ditunjukkan dengan nilai sig. $0.000<0,05$ dan nilai $t$ hitung -7,560 > t tabel 2,042. Dengan demikian dapat disimpulkan bahwa pembiayaan musyarakah secara parsial berpengaruh negatif signifikan terhadap profitabilitas (ROA) selaras dengan penelitian Sa'adah et. al (2016) mengemukakan There is a significant difference between the average financing with Mudharabah and Musharaka financing contract either supplied by $B U S$ or distributed by the BPRS.

\section{Kesimpulan}

Berdasarkan pembahasan di atas dapat disimpulkan beberapa hal berikut: pertama, secara parsial pembiayaan mudharabah berpengaruh positif dan tidak signifikan terhadap profitabilitas (ROA) pada BPRS HIK Bekasi kantor cabang Karawang dengan nilai sig. 0,187 $>\alpha 0.05$ dan nilai t hitung $=1,351<$ t tabel $=$ 2,024. Hal ini menunjukan bahwa semakin meningkatnya pembiayaan mudharabah yang dilakukan oleh bank, semakin tinggi pula tingkat profit perusahaan. Kedua, secara parsial pembiayaan musyarakah berpengaruh negatif 
signifikan terhadap profitabilitas (ROA) pada BPRS HIK Bekasi kantor cabang Karawang dengan nilai sig. $0,000<\alpha 0.05$ dan nilai t hitung $=-7,560>\mathrm{t}$ tabel $=$ 2,042. Artinya bahwa pembiayaan musyarakah pada BPRS HIK Bekasi kantor cabang Karawang berpengaruh terhadap profit perusahaan namun pengaruhnya sangat rendah. Ketiga, pembiayaan mudharabah dan musyarakah secara simultan berpengaruh signifikan terhadap profitabilitas (ROA) pada BPRS HIK Bekasi kantor cabang Karawang dengan nilai sig. $0,000<\alpha 0.05$ dan dan $\mathrm{f}$ hitung $=$ $31,022>3,32$. Hal ini menunjukan bahwa Pembiayaan mudharabah dan musyarakah secara bersama-sama memiliki pengaruh terhadap profitabilitas (ROA).

\section{Daftar Pustaka}

Agza, Y \& Darwanto. (2016). Pengaruh Pembiayaan Murabahah, Musyarakah dan Biaya Transaksi Terhadap Profitabilitas Bank Pembiayaan Rakyat Syariah. Jurnal Kajian Ekonomi dan Bisnis Islam. 10(1), 225- 245.

Arikunto \& Suharsimi. (2010). Prosedur Penelitian: Suatu Pendekatan Praktik. Rineka Cipta, Jakarta.

Amelia, E. \& Fauziah, H.E. (2017). Determinant Of Mudharaba Financing A Study At Indonesian Islamic Rural Banking. International Jurnal Etikonomi. 16(1), 43-52.

Anjani, R. \& Hasmarani, M.I. (2016). Pengaruh Pembiayaan Mudharabah, Musyarakah dan Murabahah Terhadap Profitabilitas Bank Umum Syariah Periode 2012-2015. Jurnal Menakar Peran Profesi sebagai Engine of Reform dalam Pembangunan Global Berkelanjutan. 175-183.

Ascarya. (2011). Akad \& Produk Bank Syariah. Jakarta: PT. Raja Grafindo Persada.

Ghozali, I. (2011). Aplikasi Analisis Multivariate Dengan Program IBM SPSS 19 (edisi kelima). Semarang: Universitas Diponegoro.

Harahap, SS. (2008). Analisis Kkritis Atas Laporan Keuangan. Jakarta: PT. Raja Grafindo Persada.

Harahap, S.S., Wiroso., dan Yusuf, M. (2011). Akuntansi Perbankan Syariah PSAK Syariah Baru. Jakarta: LPFE Usakti.

Harahap, S.S., Wiroso dan Yusuf M. (2010). Akuntansi Perbankan Syariah. Jakarta: LPFE Usakti.

Ismail. (2011). Perbankan Syariah. Jakarta: Kencana Prenada Media Group.

Kasmir. (2012). Manajemen Perbankan Edisi Revisi. Jakarta: Rajawali Pers.

Mamduh M.H. (2008). Manajemen Keuangan. Edisi 1, Yogyakarta: BPFE.

Muhammad. (2012). Pengantar Akuntansi Syariah. Jakarta: Salemba Empat.

Muslim, MA. \& Julimursyida. (2014). Pengaruh Pembiayaan Murabahah Dan Musyarakah Terhadap Profitabilitas (Studi Pada BPR Syariah di Indonesia). Jurnal Magister Akuntansi Pascasarjana Universitas Syiah Kuala. 
Prastowo, D. (2008). Analisis Laporan Keuangan, Edisi Kedua Sekolah Tinggi Ilmu Manajemen. YKPN.

Prihadi, T. 2010.Analisis Laporan Keuangan Teori Dan Aplikasi. Jakarta: PPM.

Priyanto. 2012. Belajar Cepat Olah Data Statistik Dengan SPSS. Yogyakarta: Cv. Andi Offest.

Nurhayati, S. \& Wasilah. (2013). Akuntansi Syariah Di Indonesia Edisi 3. Jakarta: Salemba Empat.

Sudarsono, H. (2012). Bank dan Lembaga Keuangan Syariah. Edisi Keempat. Yogyakarta: Ekonisisa.

Sugiyono. (2011). Metode Penelitian Kuantitatif Dan Kualitatif. Bandung: Alfabeta.

Sugiyono. (2012). Metode Penelitian Kuantitatif Kualitatif dan R\&D. Bandung: Alfabeta.

Sugiyono. (2013). Metode Penelitian Kualitatif Dan Kuantitatif R\&D. Bandung: Cv. Alfabeta.

Sugiyono. (2014). Metode Penelitian Kuantitatif Kualitatif dan R\&D. Bandung: Alfabeta.

Suhendi, H. (2007). Fiqih Muamalah. Jakarta. PT. Raja Grafindo Persada.

Sumiyanto, A. (2008). BMT Menuju Koperasi Modern. Yogyakarta: PT. ISES Consulting Indonesia.

Syafaruddin Alwi. (2013). Memahami perbankan syariah berkaca pada pasar umar bin khattab. Jakarta: Republika.

Syamsuddin. 2009. Manajemen Keuangan Perbankan. Jakarta: PT. Raja Grafindo Persada.

Rivai, V \& Arifin, A. (2012). Islamic Banking Sebuah Teori, Konsep dan Aplikasi. Jakarta: PT Bumi Aksara.

Wibowo, A. \& Sunarto. (2016). Pengaruh Pembiayaan Mudharabah dan Musyarakah Terhadap Profitabilitas Perbankan Syariah. Jurnal Menakar Peran Profesi sebagai Engine of Reform dalam Pembangunan Global Berkelanjutan. ISSN 2460-0784.

Sa'adah, Y. Suhel, B.A. (2016). Comparative Analysis of Profit Sharing Financing Between Islamic Banks (BUS) and Islamic Rural Bank (BPRS) in Indonesia. Internasional Journal Of Economics And Financial Issues. 7(2), 266-270. 